\title{
Lijevi ekstremizam u Saveznoj Republici Njemačkoj trideset godina nakon ujedinjenja
}

\author{
Damir Velički* \\ damir.velicki@ufzg.hr \\ https://orcid.org/0000-0001-5857-4558
}

\author{
https://doi.org/10.31192/np.18.1.2 \\ UDK: 329.055.4-028.81(430) \\ Izvorni znanstveni rad / Original scientific paper \\ Primljeno: 5. prosinca 2019. \\ Prihvaćeno: 5. veljače 2020.
}

Savezna Republika Njemačka posvećuje, zbog povijesne opterećenosti, vrlo veliku pažnju prevenciji i suzbijanju svih ekstremističkih stremljenja, pa tako $i$ lijevog ekstremizma. Preduvjet za analizu lijevoekstremističkih stremljenja u Njemačkoj je jasno definiranje samog pojma političkog, odnosno lijevog ekstremizma. Nakon toga u radu se, poslije osvrta na ideološke temelje lijevog ekstremizma, analiziraju stranke odnosno organizacije lijevoekstremističkog spektra koje djeluju na području SR Njemačke, njihovo članstvo, akcije, strategije i tematska područja djelovanja, s ciljem utvrdivanja je li lijevi ekstremizam u tom segmentu od njemačkog ujedinjenja do danas u porastu. Analizom se zaključilo da lijevi ekstremizam u SR Njemačkoj, iako nakon ujedinjenja nije niti u jednom trenutku ozbiljnije ugrozio njemačku demokraciju, nije zanemariv. On svojim ukupnim potencijalom u mnogim segmentima opterećuje demokratski poredak SR Njemačke, ali se istovremeno slojevite mjere koje njemačka država provodi radi suzbijanja i prevencije političkog ekstremizma dobro nose s lijevoekstremističkim pojavama.

Ključne riječi: lijevi ekstremizam, politički ekstremizam, SR Njemačka, ujedinjenje.

\footnotetext{
* Izv. prof. dr. sc. Damir Velički, Sveučilište u Zagrebu, Učiteljski fakultet, Savska cesta 77, HR10000 Zagreb.
} 


\section{Uvod}

Nakon završetka Drugog svjetskog rata su 1949. godine nastale dvije njemačke države. Temeljni zakon (Grundgesetz) je 23. svibnja 1949. godine stupio na snagu te je tim aktom nastala Savezna Republika Njemačka, dok je stupanjem na snagu Ustava Njemačke Demokratske Republike 7. listopada 1949. nastala druga njemačka država. Kada je 1989. godine, nakon pada Berlinskog zida, ujedinjenje dviju njemačkih država postala realna opcija, temeljem 23. članka ${ }^{1}$ Njemačka Demokratska Republika pristupila je području utjecaja Temeljnog zakona. Stoga u dokumentu koji je regulirao ujedinjenje ${ }^{2}$ ne piše izrijekom o ujedinjenju, nego se koristi pojam Beitritt - pristupanje. Usprkos tome, najčešće se govori o (ponovnom) ujedinjenju Njemačke. U Temeljnom zakonu, ali i u drugim zakonskim propisima, postoji pravni okvir kojim se nastoji očuvati pluralizam. On je vidljiv primjerice u čl. 18. u kojem se spominje i slobodarski demokratski poredak (Freiheitliche demokratische Grundordnung, krat. FdGO). Odrednice slobodarskoga demokratskog poretka nisu eksplicitno nabrojane $u$ Temeljnom zakonu, nego ga je pobliže definirao Savezni ustavni sud 1952. godine prilikom zabranjivanja Sozialistische Reichspartei Deutschlands. U obrazloženju zabrane sud ga je definirao kao poredak koji isključuje svaku vrstu nasilja i samovolje i predstavlja pravnu vladavinu na temeljima samoodređenja naroda prema volji većine, te slobode i jednakosti. U osnovna načela tog poretka moraju se uračunati: poštivanje ljudskih prava opisanih u Temeljnom zakonu, prije svega pravo čovjeka na život i razvijanje osobnosti, suverenitet naroda, odgovornost vlade prema parlamentu, zakonitost uprave, neovisnost sudova, višestranačje, ista prava za sve političke stranke s pravom na stvaranje oporbe i njezino djelovanje u skladu s ustavom. ${ }^{3}$ Četiri godine kasnije, prilikom zabrane Kommunistische Partei Deutschlands (KPD), Komunističke stranke Njemačke, 1956. godine, suci su Saveznoga ustavnog suda dodatno precizirali uvjete za zabranu stranaka. $U$ toj je presudi naglašeno da stranka nije protuustavna samim time što ne priznaje načela slobodarsko-demokratskog poretka

»nego mora postojati borbeni, agresivni stav prema postojećem poretku, te stranka mora smišljeno negativno utjecati na funkcioniranje tog poretka s ciljem njegova konačnog ukidanja«."

U SR Njemačkoj je nakon stupanja Temeljnog zakona na snagu osnovan i Savezni ured za zaštitu ustava, čiji je glavni zadatak upravo prikupljanje i vred-

\footnotetext{
${ }^{1}$ Članak 23. Temeljnog zakona koji je definirao pripajanje kasnije je, zakonom od 21. prosinca 1992., koji je stupio na snagu 25. prosinca 1992., zamijenjen člankom o »ostvarenju jedne ujedinjene Europe« (Dieter HESSELBERGER, Das Grundgesetz. Kommentar für die politische Bildung, Sonderausgabe für die Landeszentralen für politische Bildung, München, ${ }^{13} 2003$ ).

2 Der Vertrag über die Herstellung der Einheit Deutschlands.

3 BverfGE, 2, 1, SRP - Verbot.

${ }^{4}$ BverfGe, 5, 85.
} 
novanje informacija o stremljenjima koja su usmjerena protiv slobodarskog demokratskog poretka ${ }^{5}$, a u njih se, između ostalih, ubraja i politički ekstremizam. Nijemci vrlo veliku pažnju posvećuju prevenciji i suzbijanju svih ekstremističkih stremljenja, pa tako i lijevog ekstremizma. Preduvjet za analizu lijevoekstremističkih stremljenja u Njemačkoj je jasno definiranje samog pojma političkog odnosno lijevog ekstremizma, stoga će o tome biti riječi u nastavku rada.

\section{Politički ekstremizam}

Leggewie i Meier su definiranje pojma ekstremizma usporedili s »definiranjem zavojitih stepenica ${ }^{6}{ }^{6}$ Backes i Jesse kreću od antagonističkih pozicija ekstremizma i demokracije te definiraju politički ekstremizam kao

»skupni pojam za različite političke stavove i nastojanja koja odbijaju demokratsku ustavnu državu i njezine osnovne vrijednosti, bilo da negiraju načelo ljudske jednakosti (desni ekstremizam), bilo da žele načelo jednakosti proširiti na sva životna područja, prekrivajući i ideju individualne slobode (komunizam), bilo da bilo koji oblik državnosti označavaju represivnim (anarhizam) «?

Pritom se nipošto ne negiraju ključne razlike između lijevog i desnog ekstremizma i njihovi različiti ciljevi, ali to istovremeno ne znači da lijevi i desni ekstremizam nemaju zajedničkih strukturnih obilježja. Međutim, za potpuno razumijevanje navedene definicije političkog ekstremizma moraju se pobliže definirati i obilježja demokratske ustavne države, a u njih možemo ubrojiti diobu vlasti, poštivanje ljudskih prava, pravnu državu, pluralizam te narodni suverenitet. ${ }^{8}$ Usprkos tome, postojeća definicija precizno ne objašnjava što ekstremizam jest, nego više što ekstremizam nije. Backes stoga nadopunjuje postojeću definiciju obilježjima koje imaju svi oblici ekstremističkih pojava, bez obzira na razlike u ideološkom smislu, a u njih ubraja dogmatizam, poimanje svijeta koje polazi od apsolutnih istina, utopizam, stereotipe prijatelj-neprijatelj, teorije zavjere, fanatizam i aktivizam. ${ }^{9}$

Slične značajke razradio je i Pfahl-Traughber, koji je istaknuo da lijevi, desni, te religiozni ekstremisti vjeruju da posjeduju ekskluzivno pravo na spoznaju

\footnotetext{
${ }^{5}$ Prema čl. 3 Bundesverfassungsschutzgesetz (BVerfSchG) o zadatcima organa za zaštitu ustava.

${ }^{6}$ Claus LEGGEWIE, Horst MEIER, Republikschutz. Maßstäbe für die Verteidigung der Demokratie, Reinbek bei Hamburg, 1995, 225.

7 Uwe BACKES, Eckhard JESSE, Politischer Extremismus in der Bundesrepublik Deutschland, Bonn, 1996, 45.

${ }^{8}$ Birgit ENZMANN, Der demokratische Verfassungsstaat. Entstehung, Elemente, Herausforderungen, Wiesbaden, 2012; Peter Graf KIELMANSEGG, Die Grammatik der Freiheit. Acht Versuche über den demokratischen Verfassungsstaat, Baden-Baden, 2013.

9 Uwe BACKES, Politischer Extremismus in demokratischen Verfassungsstaaten, Wiesbaden, 1989, 298-311.
} 
i tvrde da je ispravnost njihovih pozicija apsolutno nedvojbena. Oni tvrde da jedino oni mogu spoznati pravu bit stvari, znaju koji je povijesni put unaprijed zadan te pritom teže potpunoj kontroli i političkoj homogenizaciji društva. Osim toga, političke ekstremiste karakterizira dualistička rigoroznost, odnosno razmišljanje u beskopromisnim suprotnostima poput dobro - loše. ${ }^{10}$ Normativna definicija jasno diferencira između lijevoekstremističke i desnoekstremističke varijante.

Međutim, podjela »lijevoekstremistički« i »desnoekstremistički« sekundarne je prirode i njezin je cilj kategorizacija fenomena. Os »lijevo-desno « nije identična s osi »demokracija - ekstremizam«, a »normativni koncept utoliko ne bi bio jednodimenzionalan, nego dvodimenzionalan «. ${ }^{11} \mathrm{Na}$ samom kraju mora se reći da je politički ekstremizam složen fenomen, ekstremistički ciljevi i stremljenja mogu poprimiti različit intenzitet. Zbog toga se navedene značajke ne smiju shvatiti isključivo kao cjelina. Uz zajedničke crte postoje i bitne razlike te je sljedeći korak razmatranje značajki koji neki ekstremistički fenomen čine lijevoekstremističkim, budući da je fokus ovoga rada usmjeren upravo na njega, i to na području SR Njemačke. Analiza će se pritom, vremenski gledano, ograničiti na razdoblje od ujedinjenja dviju njemačkih država 1990. godine do danas.

\section{Značajke lijevog ekstremizma}

Moreau i Lang su 1996. godine ustvrdili da je lijevi ekstremizam podcijenjena opasnost ${ }^{12} \mathrm{i}$ da se znatno više piše i objavljuje o desnom ekstremizmu, nego o lijevom. Možda se opširnija literatura o desnom ekstremizmu prvih nekoliko godina nakon ujedinjenja i mogla objasniti aktualnim događajima u SR Njemačkoj kada je zabilježen porast desnoekstremističkog nasilja, ali činjenica je da se i danas na njemačkom govornom području više piše i govori o desnom ekstremizmu ${ }^{13}$, odnosno posljednjih godina, a zbog aktualnih svjetskih zbivanja, o islamskom fundamentalizmu. Međutim, razloge za manji (znanstveni) interes za lijevi ekstremizam ne treba tražiti isključivo u aktualnim društvenopolitičkim događanjima. Razlozi su višestruki, a možemo ih izdvojiti tri. Prvo,

${ }^{10}$ Armin PFAHL-TRAUGHBER, Gemeinsamkeiten im Denken der Feinde einer offenen Gesellschaft. Strukturmerkmale extremistischer Doktrin, u: isti (ur.), Jahrbuch für Extremismus- und Terrorismusforschung 2009/2010, Brühl, 2010, 9-32.

${ }^{11}$ Jürgen P. LANG, Was ist Extremismusforschung? Theoretische Grundlagen und Bestandsaufnahme, u: Uwe BACKES, Eckhard JESSE (ur.), Gefährdungen der Freiheit. Extremistische Ideologien im Vergleich, Göttingen, 2006, 41-86, 48.

${ }^{12}$ Patrick MOREAU, Jürgen LANG, Linksextremismus - Eine unterschätzte Gefahr, u: Uwe BACKES, Eckhard JESSE (ur.), Schriftenreihe Extremismus \& Demokratie, sv. 8, Bonn, 1996.

${ }^{13} \mathrm{O}$ terminološkom razgraničenju ekstremizma i radikalizma opširnije usp. Damir VELIČKI, Desni ekstremizam, radikalizam i zapadnoeuropska Nova desnica, Politička misao, 47 (2010) 2, 67-84. 
Ceylanoglu naglašava da lijevoekstremističke stranke i pokreti, za razliku od desnoekstremističkih, često uspijevaju povećati svoj utjecaj stvarajući saveze s demokratskim strankama ili organizacijama, a

»natprosječni nivo obrazovanja pripadnika lijevoekstremističkih organizacija otvara im mogućnost boljeg utjecaja na javno mnijenje, nego pripadnicima desnoekstremističkih ideologija i organizacija koji većinom imaju nizak stupanj obrazovanja«. ${ }^{14}$

Drugo, koliko se tema lijevog ekstremizma uopće pojavljuje u kurikulima školskih predmeta u SR Njemačkoj, odnosno koliko joj se pažnje uopće polaže u školstvu, odnosno samim time i prevenciji? U prosincu 2018. godine je renomirana znanstvena ustanova Georg-Eckert Institut - Leibniz - Institut für internationale Schulbuchforschung objavila rezultate analize školskih udžbenika i kurikula u Njemačkoj o temi ekstremizma. Rezultati su pokazali da se ekstremizam bez iznimke opisuje kao prijetnja demokratskom poretku, a da se najčešće obrađuje tema desnog ekstremizma. ${ }^{15}$

Treće, može se steći dojam da je lijevi ekstremizam, zbog cilja kojem teži, društveno znatno prihvatljiviji. Desnoekstremistička ideologija s izraženim nacionalističkim i rasističkim crtama može na prosječnog promatrača ostaviti na prvi pogled mnogo negativniji i problematičniji dojam nego lijevoekstremistička retorika s ustrajanjem na nužnosti jednakosti svih ljudi. Može se reći da lijevoekstremističke doktrine jesu naoko u skladu s idejom demokratske ustavne države što se tiče naglašavanja temeljne ljudske jednakosti. Ali iz tog etičkog temeljnog načela one izvlače ekstremne zaključke time što "postuliraju totalno oslobađanje čovjeka od svih političkih, ekonomskih i kulturnih prisila i smatraju mogućim ostvarenje bezvlasnog poretka slobodnih i jednakih ljudi«. ${ }^{16}$ Utopijski karakter lijevog ekstremizma vidljiv je u vjerovanju o nastanku »novog čovjeka« koji će raskinuti sve spone s poznatim povijesnim oblicima oblikovanja društva i ostvariti stanje krajnjeg zadovoljstva i sklada na zemlji. I Everts jasno naglašava da "priznavanje temeljne ljudske jednakosti uključuje $u$ sebi i poštivanje individualnosti i različitosti ljudskih htijenja, kao i poštivanje pluralizma u društvu i različitih političkih koncepata«. ${ }^{17}$

Ceylanoglu također ističe da se lijevi ekstremisti vide kao dio emancipacijskog pokreta koji se zalaže za podizanje vrijednosti građanskih prava i poboljšavanje životnih uvjeta i uvjeta rada neprivilegiranih slojeva. Pritom se pozivaju

\footnotetext{
${ }^{14}$ Sena CEYLANOGLU, Linksextremismus in Deutschland heute, u: Extremismus in Deutschland. Erscheinungsformen und aktuelle Bestandsaufnahme, Berlin, 2004, 136-162, 137.

${ }^{15}$ Eleni CHRISTODOULOU, Simona SZAKÁCS, Preventing Violent Extremism through Education: International and German Approaches, Braunschweig, 2018; https://repository.gei.de/ (16.10.2019).

${ }^{16}$ Uwe BACKES, Eckhard JESSE, Politischer Extremismus in der Bundesrepublik Deutschland, Bonn, 1996, 60.

${ }^{17}$ Carmen EVERTS, Politischer Extremismus. Theorie und Analyse am Beispiel der Parteien REP und PDS, Berlin, 2000, 183.
} 
na to da se, historijski gledano, postupno ostvarenje tih ciljeva i može zahvaliti političkoj ljevici. To je vrlo vjerojatno i razlog što ponekad borba države protiv lijevog ekstremizma dobiva negativnu konotaciju »kao da se represivna država opire da svojim građanima osigura prava koja im pripadaju kao i socijalnu sigurnost ${ }^{18}{ }^{18}$ Mora se jasno reći da suzbijanje lijevog ekstremizma s time nema nikakve veze, nego da je demokratska ustavna država prisiljena braniti osnovna demokratska načela. Da bismo što je moguće preciznije sadržajno konkretizirali lijevi ekstremizam, potrebno je, osim navedenih značajki, ukratko analizirati i definiciju lijevog ekstremizma kao

»organizacije ili osobe koje negiraju kapitalizam (komunisti) ili svaku vrstu vladavine (anarhisti, tzv. 'Autonome'). Jedni žele - barem teoretski - svu vlast radničkoj klasi, a anarhisti vlast nikome. «19

Sama kritika kapitalizma nije automatski i antidemokratska, pojam antikapitalizma valja uravnoteženo upotrebljavati, jer bi se mogao steći dojam da je »sama kritika SR Njemačke kao kapitalističke, imperijalističke i rasističke ekstremistički napad na demokratsku ustavnu državu «. ${ }^{20}$ Pitanje socijalne nejednakosti i nepravde, kritika raspodjele prihoda i bogatstava, teme su kojima se ne bave isključivo lijevi ekstremisti, one, više ili manje, postoje u svim dijelovima političkog spektra, stoga je »neopravdano paušalno obilježavanje kritike kapitalizma antidemokratskom «. ${ }^{21}$ Bitno je koja se konkretna alternativa nudi, odnosno, upotrebom kojih sredstava bi se ona mogla ostvariti. Ako je riječ o prevladavanju kapitalizma revolucijom te o želji realizacije komunističkog društva kako je dosad opisano, onda se može govoriti o lijevom ekstremizmu. Nadalje, svi politički ekstremisti polaze od apsolutnih istina i zatvorenih misaonih tvorevina. Konkretno, lijevi ekstremisti čvrsto vjeruju u povijesnu misiju radničke klase, diktaturu proletarijata, »besklasno društvo « i borbu protiv »kapitalističkog izrabljivanja«, ali ne smatraju to političkim programima o kojima bi se trebalo kritički razgovarati, nego polaze od nedvojbenosti vlastitih pozicija. I lijevi i desni ekstremisti odbijaju pomisao vladavine na određeno vrijeme, ne žele stalnu kontrolu političkog vodstva. Još se može naglasiti da su ideološki temelji lijevog ekstremizma u SR Njemačkoj marksizam-lenjinizam, trockizam, maoizam i anarhizam, što rezultira raznolikošću lijevoekstremističkih strujanja.

\footnotetext{
${ }^{18}$ Isto, 140.

${ }^{19}$ Steffen KAILITZ, Politischer Extremismus in der Bundesrepublik Deutschland. Eine Einführung, Wiesbaden, 2004, 22.

${ }^{20}$ Gero NEUGEBAUER, Extremismus - Rechtsextremismus - Linksextremismus, u: Wilfried SCHUBARTH, Richard STÖSS (ur.), Rechtsextremismus in der Bundesrepublik Deutschland. Eine Bilanz, Bonn, 2000, 13-37, 22.

${ }^{21}$ Isto.
} 


\section{Tematska područja lijevog ekstremizma u SR Njemačkoj}

Prema mišljenju lijevih ekstremista u SR Njemačkoj, iz kapitalizma izviru i brojni drugi društvenopolitički fenomeni protiv kojih se valja boriti, stoga se može konstatirati da lijevi ekstremisti danas u SR Njemačkoj "pokrivaju» sljedeća tematska područja: antifašizam, antirasizam, antiglobalizaciju, antirepresiju i antigentrifikaciju. ${ }^{22}$ Međutim, poimanje navedenih pojmova iz perspektive lijevih ekstremista ne možemo poistovjetiti s njihovim poimanjem iz demokratske perspektive. Stoga Backes i Jesse pozivaju na oprez prilikom uporabe pojma »antifašist « u znanstvenom diskursu, budući da taj pojam sugerira da je biti »antifašist « dokaz demokratskih nazora. ${ }^{23}$ To je potreban, ali svakako nedovoljan uvjet i dokaz demokratskih stavova.

Međutim, sam pojam "antifašizam" svakako je prihvatljiviji pojam za mobilizaciju masa od pojma »komunizam«. Pojmovi poput »antifašizam«, tj. "antikomunizam« kojeg upotrebljavaju desni ekstremisti, vrlo su prikladni za prikrivanje ekstremističkih nazora. Za lijeve ekstremiste državno i društveno uređenje SR Njemačke latentno sadrži fašističke značajke jer smatraju da državnomonopolistički kapitalizam upotrebljava fašističke tendencije koje postoje u društvu. Samo ukidanje kapitalizma i s njime povezano prevladavanje klasnih razlika vodi ukidanju fašizma. Aktivnosti "antifašističkih « lijevih ekstremista (Antifa), često popraćene nasiljem, usmjerene su samo dijelom protiv desnih ekstremista. Pravi cilj je zapravo "građansko-demokratska« država, a pravi antifašist je onaj koji se bori protiv građanskog društvenog poretka. Lijevi ekstremisti vide, nadalje, »kapitalističko društvo« obilježeno ne samo fašizmom, nego i rasizmom. Naravno da rasizam iz perspektive lijevih ekstremista ne možemo poistovjetiti s poimanjem rasizma iz demokratskog ugla. Prema shvaćanju lijevih ekstremista, kapitalizam najviše pogađa izbjeglice, strance i azilante, budući da su oni primorani prodavati svoju radnu snagu bez socijalne sigurnosti, ali izrabljivanje i obespravljivanje odnosi se načelno na sve ljude koje žive u kapitalizmu. Vlade kapitalističkih država, prema mišljenju lijevih ekstremista, također provode rasističku politiku, jer kreiraju svoju politiku prema zahtjevima kapitala.

Kao još jedno tematsko područje lijevih ekstremista mogla bi se dodati i »antiglobalizacija«. U sklopu lijevog ekstremizma se ta tema izjednačuje s grabežljivim kapitalizmom koji ima za posljedicu stvaranje još većih razlika između bogatih i siromašnih. ${ }^{24}$ Naposljetku, svakako treba pojasniti i borbu

\footnotetext{
${ }^{22}$ Na njemačkom govornom području DUDEN bilježi pojam Gentrifizierung te ga definira kao »podizanje vrijednosti dijela grada sanacijom i adaptacijom, s posljedicom da bogatiji slojevi stanovništva potiskuju tamo nastanjeno stanovništvo «.

${ }^{23}$ Uwe BACKES, Eckhard JESSE, Politischer Extremismus in der Bundesrepublik Deutschland, Bonn, 1996, 520.

${ }^{24}$ Rudolf van HÜLLEN, Linksextremisten. Avantgarde oder Randerscheinung in der Anti-Globalisierungsbewegung?, u: Bundesamt für Verfassungsschutz (ur.), Politischer Extremismus in
} 
lijevih ekstremista protiv gentrifikacije, dakle saniranja starijih dijelova grada te posljedično potiskivanja tamošnjeg stanovništva koje mora uzmaknuti pred bogatijim slojevima društva. Gentrifikacijom se, ne samo iz perspektive lijevih ekstremista, generira socijalna nejednakost, stoga kritika te pojave svakako može biti dio legitimnog demokratskog diskursa.

Međutim, lijevi ekstremisti koriste temu gentrifikacije kao izliku za proteste koji obiluju nasiljem. Osim toga, budući da smatraju da se bore za slobodu i pravo na samoodređenje, za sebe zahtijevaju »slobodan prostor« za djelovanje. Drugim riječima, smatraju da imaju potpuno pravo (ilegalno) zaposjesti kuće i stanove, kulturne centre i druge objekte koji im istovremeno služe kao mjesto indoktrinacije podmlatka i prikupljanja financijskih sredstava. Jedno od takvih primjera je Rote Flora u Hamburgu. Rote Flora je tzv. autonomni centar (Autonomes Zentrum), koji je ilegalno zaposjednut još davne 1989. godine. ${ }^{25}$

Osim navedenih, moramo spomenuti i tzv. »Antideutsche«, posebnu grupaciju lijevih ekstremista čije je tematsko područje djelovanja odbijanje postojanja njemačke nacije. Upravo tu grupaciju karakterizira činjenica da su njezine ideološke pozicije nastale primarno nakon njemačkog ujedinjenja, kada su dijelovi lijevoekstremističkog spektra u ujedinjenju vidjeli veliku opasnost stvaranja velikonjemačkog »Četvrtog Reicha« i jačanje njemačkog nacionalizma. Budući da oni njemačkom narodu pripisuju sklonost fašizmu, smatraju da je potreban potpuni odmak od postojanja njemačke nacije koja mora biti integrirana u multikulturalno društvo. »Antideutsche« doista zauzimaju posebno mjesto u lijevoekstremističkom spektru zato što, a budući da pokazuju bezuvjetnu solidarnost s državom Izrael, odbijaju i svaku kritiku SAD-a kao zemlje koja podržava Izrael. Taj stav je nepremostivo proturječje s ostalim lijevoekstremističkim grupacijama koje karakterizira izrazito antiimperijalistički stav, a s njime u pravilu i kritika SAD-a.

Na kraju ovog dijela potrebno je naglasiti da je politički ekstremizam vrlo složen fenomen, a analiza ekstremističkih pojava obuhvaća više razina, od analize stranaka i organizacija, do političkih stavova birača i članstva ekstremističkih stranaka, te ekstremističkih akcija i strategija. U nastavku će se prvenstveno analizirati stranke odnosno organizacije lijevoekstremističkog spektra koje djeluju na području SR Njemačke, njihovo članstvo, akcije i strategije, te će se utvrditi je li lijevi ekstremizam u tom segmentu od njemačkog ujedinjenja do danas u porastu. Analiza stavova birača i članstva lijevoekstremističkih stranaka i organizacija, a s obzirom na ograničen propisani opseg rada u znanstvenom časopisu te opsežnost teme, spomenut će se samo u osnovnim crtama.

der Ära der Globalisierung. Ein Symposion des Bundesamtes für Verfassungsschutz, 20.06.2002. Beiträge, Köln, 2003, 67-76.

${ }^{25}$ Vidi: https://rote-flora.de/ (01.10.2019). 


\section{Lijevoekstremističke stranke i organizacije u SR Njemačkoj- članstvo i akcijski oblici}

Lijeve ekstremiste u SR Njemačkoj možemo, sažeto prikazano, podijeliti u dvije osnovne grupe: tzv. "autonome« i ortodoksne komuniste. Utoliko se možemo složiti s formulacijom da

»u skupni pojam lijevi ekstremisti u SR Njemačkoj ulaze anarhisti, koji negiraju centralne organizacijske oblike, 'autonomne' grupacije koje ne priznaju autoritete - granica prema terorizmu je u njihovom slučaju fluidna - kao i različite varijante komunizma«. ${ }^{26}$

One se pozivaju na učenje Marxa i Engelsa, Lenjina, Staljina, Trockog ili Mao Ce-tunga. Osnovna je razlika između militantnih lijevih ekstremista i ortodoksnih komunista što ortodoksni komunisti primjenu sile smatraju legitimnom i neizbježnom u revolucionarnoj situaciji, pri čemu vodeća stranka, "avangarda ima pravo primijeniti silu. Ta grupa lijevih ekstremista djeluje uglavnom kroz stranke i organizacije, dok anarhističko orijentirane grupe, a među njima već spomenute tzv. autonomne grupacije - »Autonome«, nisu niti ideološki niti strategijski homogene. One odbijaju svaku vrstu hijerarhija i ne vide uzor u autoritarnim, odnosno totalitarnim režimima, njih karakterizira izraziti individualizam koji stoji $\mathrm{u}$ jasnoj suprotnosti s kolektivizmom ortodoksnih komunista. Istovremeno, »Autonome « primjenu nasilja - i protiv osoba vide kao neizbježno sredstvo protiv »prisile, izrabljivanja i ugnjetavanja« i kao cijenu koju država mora platiti za održavanje postojećeg poretka.

Budući da su "Autonome« najbrojnija grupacija lijevih ekstremista u SR Njemačkoj, potrebno je opširnije osvrnuti se na razloge njihovog nastanka. "Autonome«, autonomni, proizašli su iz studentskog pokreta 60-tih godina. Brojne grupe tog nedogmatskog pokreta karakteriziraju od početka neke zajedničke crte: oni se bore protiv postojećeg državnog i društvenog poretka, žustro odbijaju marksizam-lenjinizam kojega nazivaju dogmatskim i birokratskim. Zalažu se za spontanost, autonomnost i samoorganizaciju »potlačenih« i prije svega žele djelovati u »bazi« (gradske četvrti, fakulteti i sl.) kako bi iskoristili svaku mogućnost revolucionarnog otpora.

"Autonome«, dakle, nemaju državni uzor, oni su konglomerat talijanskih i »spontanih « uzora. Upravo ovi posljednji pojavili su se sredinom sedamdesetih godina s ciljem da bez nepotrebnog oklijevanja krenu u akciju, dakle spontano. Sukladno tome su sebe nazvali »Spontis« (u nastavku teksta ostavit će se i taj originalni naziv). Glavno obilježje »Spontisa« bio je ekstreman individualizam. Glavni neprijatelj bila je država jer je sprječavala razvitak pojedinca, a nasilje su iskazivali uglavnom u okviru demonstracija - bacanjem kamenja, tzv. Mo-

\footnotetext{
${ }^{26}$ Eckhard JESSE, Linksextremismus, u: Everhard HOLTMANN (ur.), Politik-Lexikon, München - Beč, 2000, 356.
} 
lotovljevim koktelima i sl. Kao trenutak prijelaza u »autonoman pokret « može se označiti 1978. godina, kada nakon Tunix kongresa na Technische Universität Berlin dolazi do osipanja "Spontisa«, odnosno kada dio njih kao »autonomni« postaju nasljednici njihova militantnog krila. ${ }^{27}$ Prvi susret autonomnih na saveznoj razini, s oko 250 sudionika, održao se u Hannoveru u veljači 1983. ${ }^{28}$

"Autonome« nemaju jedinstven ideološki ili strateški koncept. Bilo koje teoretsko utemeljenje im je sumnjivo i u suprotnosti je s njihovim zahtjevom da žive prema vlastitim zakonima, dakle autonomno. Oni se zadovoljavaju osnovnim osjećajem militantne antidržavnosti, odbijanjem autoriteta i hijerarhija, kao uostalom i plaćenog rada; odbijanje regularnog posla smatra se protestnim ponašanjem, kao individualno prevladavanje kapitalističkih struktura. Mora se primijetiti da ih, unatoč tome, to ne sprječava da žive od socijalne pomoći, odnosno od neke druge vrste državne financijske potpore. Pfahl-Traughber i Berndt naglašavaju da je osnovni stav "Autonome« "generalno političko protivljenje državi i društvu, koje potpuno svjesno u političkim aktivnostima uključuje kršenje zakona«. ${ }^{29}$ Iako nisu homogen pokret, ipak su jedinstveni u spremnosti upotrebe nasilja da bi proveli svoje ciljeve. Empirijski podaci o njihovoj socijalnoj pozadini izuzetno su rijetki, ali se uglavnom radi »o muškarcima do 30 godina starosti, od kojih se mnogi nalaze u nekom stupnju školovanja, odnosno studiraju «. ${ }^{30}$

Što se tiče stranaka i ostalih organizacija, prvo je potrebno preciznije se osvrnuti na stranku DIE LINKE. Stranka je nasljednica istočnonjemačkog SED-a (od 1990. godine PDS), ${ }^{31}$ a u svojoj je povijesti nekoliko puna mijenjala ime. Ona je u parlamentima svih istočnonjemačkih pokrajina kao i u Bundestagu zastupljena od 1990. godine. Godine 2007. uspjela je ući i u parlament jedne zapadnonjemačke pokrajine, a nakon toga i u većinu ostalih. Na saveznim parlamentarnim izborima 2017. godine osvojila je 9,2 \% glasova i 69 mandata. DIE LINKE u cjelini ne bismo mogli okarakterizirati lijevoekstremističkom, iako i njemački politolozi o tome imaju djelomice suprotstavljena mišljenja. ${ }^{32}$ Stranka je godinama bila pod prismotrom Saveznog ureda za zaštitu ustava, no od 2014. godine to više nije slučaj.

\footnotetext{
${ }^{27}$ Michael MÄRZ, Linker Protest nach dem Deutschen Herbst. Eine Geschichte des linken Spektrums im Schatten des »starken Staates«, 1977 - 1979, Bielefeld, 2012.

${ }^{28}$ Gerd LANGGUTH, Protestbewegung: Entwicklung, Niedergang, Renaissance: die neue Linke seit 1968, Köln, 1984, 241.

${ }^{29}$ Armin PFAHL-TRAUGHBER, Uwe BERNDT, Extremismus und innere Sicherheit, u: Werner WEIDENFELD, Karl-Rudolf KORTE (ur.), Handbuch zur deutschen Einheit 1949-1989-1999, Bonn, 1999, 357.

${ }^{30}$ Linksextremismus. Erscheinungsformen und Gefährdungspotenziale, Bundesamt für Verfassungsschutz, 2016, 8.

${ }^{31}$ Damir VELIČKI, Stranka demokratskog socijalizma (PDS) u političkom sustavu Njemačke, Politička misao, 39 (2002) 1, 139-158.

${ }^{32}$ Frank DECKER, Viola NEU, Handbuch der deutschen Parteien, Wiesbaden, 2007; Eckhard JESSE, Jürgen P. LANG, Die Linke - der smarte Extremismus einer deutschen Partei, München, 2008.
} 
Međutim, unutar stranke djeluju već godinama neke platforme koje se mogu okarakterizirati lijevoekstremističkim, te su još uvijek pod povećalom Saveznog ureda za zaštitu ustava. Tako npr. unutar stranke djeluje »Kommunistische Platform « (KPF) koja, prema postojećem statutu, predstavlja »socijalističku alternativu postojećem kapitalističkom sustavu« i oslanja se i dalje na marksističko-lenjinističku tradiciju. Članovi nastoje unutar stranke DIE LINKE proširiti svoja stajališta, a pritom surađuju s ostalim lijevoekstremističkim organizacijama. »Kommunistische Platform» brani historijski legitimitet Demokratske Republike Njemačke, a za širenje svojih političkih i ideoloških pogleda izdaje mjesečnik "Mitteilungen der Kommunistischen Platform«. »Kommunistische Platform« ima oko 1.200 članova.

Od ostalih grupacija unutar stranke DIE LINKE svakako moramo spomenuti »Sozialistische Linke« koja također zastupa neomarksističke pozicije. Kao cilj svojih nastojanja oni navode prevladavanje kapitalizma, a bivši DDR je za njih bio »legitiman pokušaj da se na njemačkom tlu izgradi alternativa kapitalizmu«. »Sozialistische Linke« broji oko 800 članova, a izdaju publikaciju pod znakovitim naslovom »Realistisch und radikal«.

Nadalje, od stranaka lijevoekstremističkog spektra možemo istaknuti »Deutsche Kommunistische Partei«, osnovanu 1968. godine. Stranka se smatra političkom nasljednicom »Kommunistische Partei Deutschlands« koju je Savezni ustavni sud zabranio 1956. godine. Program stranke temeljio se na programu stranke KPD, jedino su prošireni oni dijelovi koji su poslužili Saveznom ustavnom sudu da obrazloži njezino zabranjivanje. Tako, primjerice, više nije bilo riječi o diktaturi proletarijata, nego o »demokratskoj obnovi države i društva « i sl. Kraj sovjetskog imperija i »realnog socijalizma« doveo je i do jake političko-ideološke, ali nadasve financijske krize stranke. Nedostatak novaca uzrokovao je i ograničavanje političkih aktivnosti, a broj članova je s početnih 9.000 članova 1968. godine, krajem sedamdesetih doživio vrhunac (1977.: 42.000), a nakon ujedinjenja je kontinuirano u opadanju (1990.: 22.000, 1991.: 11.000, 2000.: 5.000, 2017.: 3.000). ${ }^{33}$

Unatoč tome, središnji cilj stranke je i dalje »uspostava komunističkog sustava«, ali se unutar stranke od 2009. godine vodi žestoka diskusija oko ideološkog pravca stranke. Dio stranke želi povratak na izvorno učenje marksizmalenjinizma, dok se dio stranke zalaže za relativiziranje značenja radničke klase kao revolucionarnog subjekta i avangardne uloge stranke. Stranka na saveznim parlamentarnim izborima postiže zanemariv uspjeh, primjerice 2017. dobila je 11.558 glasova (Zweitstimmen), ${ }^{34}$ a na izborima za Europski parlament 2019.

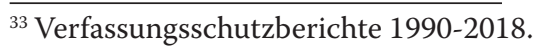

${ }^{34}$ https://www.bundeswahlleiter.de/bundestagswahlen/2017/ergebnisse/bund-99.html (04.12.2019).
} 
godine 20.419 glasova (2014.: 25.147), što je, prema vlastitim navodima stranke, »alarmantan znak koliko je DKP slabo ukorijenjena u radničkoj klasi«. ${ }^{35}$

Sljedeća stranka kojoj valja obratiti pozornost je »Marxistisch-Leninistische Partei Deutschlands« (MLPD), osnovana 1982. godine, a proizašla zapravo iz već 1972. godine osnovanog Komunističkog saveza radnika Njemačke - »Kommunistischer Arbeiterbund Deutschlands« (KABD). Sjedište stranke je u Gelsenkirchenu. Stranka MLPD ostale lijevoekstremističke stranke, kao npr. DKP, ali i stranku DIE LINKE, karakterizira kao glavne nosioce modernog revizionizma, te $u$ svojem statutu ističe: "Da bi se pripremio novi uspon $u$ borbi za socijalizam, potrebno je odlučno ograditi se od tih revizionističkih i izopačenih komunista. «36

Stranka je unatoč slomu istočnog bloka broj svojih članova sredinom devedesetih godina dvadesetog stoljeća uspjela povećati (1990.: 1.400, 1993.: 1.700, 1995.: 2.300, 1996.: 2.700, 2005.: 2.300). ${ }^{37}$ Međutim, nakon toga broj članova počeo se smanjivati, pa je stranka 2016. i 2017. godine imala 1.800 članova. ${ }^{38}$ Područje djelovanja stranke je politički rad u tvornicama i sindikatima. U svojim aktivnostima stranka se oslanja na svoju publikaciju »Rote Fahne» (»Crvena zastava«), kao i na brojne ostale brošure i letke. Godine 1992. osnovan je i klub mladih »Rebell«. MLPD je kao maoističko-staljinistički orijentirana stranka izolirana čak i od ostalih lijevoekstremističkih stranaka i organizacija. Na izborima za Bundestag stranka postiže statistički irelevantne uspjehe, 2017. godine osvojila je $0,1 \%$, odnosno 29.785 glasova (Zweitstimmen). ${ }^{39}$ Zanimljivo je da je stranka, unatoč malom broju članova i zanemarivim izbornim uspjesima, već godinama $\mathrm{u}$ »upadljivo dobroj financijskoj situaciji. Ona dobiva prihode od članarina te neproporcionalnih velikih donacija «. ${ }^{40}$

U lijevoekstremistički potencijal u SR Njemačkoj valja još pribrojiti i brojne trockističke grupe. Trockiste karakterizira sklonost odcjepljenju, jer si trockističke grupe međusobno predbacuju krivo, odnosno izdajničko tumačenje ideja i strateških preporuka Trockog. Budući da su organizacijski rascjepkane i ne mogu zbog toga razviti veći politički utjecaj, trockisti koriste metodu infiltracije, tzv. entrizma, a pod tim pojmom se misli na »otvoreni ili prikriveni ulazak $\mathrm{u}$ druge pokrete, organizacije ili stranke $"{ }^{41} \mathrm{u}$ nastojanju da se na njih djeluje iznutra. Kao najvažnije trockističke grupe treba spomenuti »Sozialistische Alternative» (SAV) s oko 300 članova i "Gruppe ArbeiterInnenmacht» (GAM)

\footnotetext{
${ }^{35}$ Homepage DKP, http://blog.unsere-zeit.de/?p=2185 (17.10.2019).

${ }^{36}$ Homepage MLPD, https://www.mlpd-mannheim.de/ueber-uns/grundsaetze-und-statut/ praeambel (17.10.2019).

${ }^{37}$ Podaci iz godišnjih izvještaja Službe za zaštitu ustava.

${ }^{38}$ Verfassungsschutzbericht 2017, 130.

${ }^{39}$ https://www.bundeswahlleiter.de/bundestagswahlen/2017/ergebnisse/bund-99.html (04.12.2019).

${ }^{40}$ Verfassungsschutzbericht, 2017, 130.

${ }^{41}$ Armin PFAHL-TRAUGHBER, Linksextremismus in Deutschland. Eine kritische Bestandsaufnahme, Wiesbaden, 2014, 128
} 
S oko 40 članova, odnosno njihova organizacija mladeži »REVOLUTION« (REVO) sa 60 članova. Od ostalih većih organizacija i stranaka, možemo još spomenuti "Marxistisches Forum» (MF) s oko 400 članova, "Marx21« s 300 članova.

Što se tiče lijevoekstremističkog ljudskog potencijala od njemačkog ujedinjenja do danas, analizu možemo započeti s 1992. godinom. Naime, te je godine objavljeno prvo svenjemačko izvješće Ureda za zaštitu ustava te je pritom zabilježeno 980 nasilnih djela lijevih ekstremista, a ukupan broj lijevih ekstremista procijenjen je na oko 29.000, odnosno tom broju valjalo je pridodati još 12.000 ljudi koji su djelovali u organizacijama i grupama koji su bili pod utjecajem lijevih ekstremista. Broj članova "Autonome« spremnih na nasilje procijenjen je na 5.000 osoba. ${ }^{42}$ Sredinom narednog desetljeća, krajem 2005. godine, kada se oduzmu višestruka članstva, u SR Njemačkoj je lijevoekstremistički ljudski potencijal, brojčano gledano, izgledao ovako: Ukupno je bilo približno 30.600 ljudi u lijevoekstremističkim strankama, organizacijama ili skupinama (2004: 30.800). Tu su bili ubrojeni i članovi »Kommunistische Platform» stranke »Die Linkspartei. PDS «, čiji se broj procjenjivao na oko 1.000. Spektar nasilnih lijevih ekstremista procijenjen je na oko 5.500 osoba, od koji 5.000 »Autonome«. U marksističkim-lenjinističkim, trockističkim i ostalim revolucionarnim strankama i organizacijama 2005. godine bilo je oko 25.400 ljudi (2004: 25.700). Time je ukupan lijevoekstremistički ljudski potencijal 2005. godine, u odnosu na prethodne dvije godine, bio neznatno manji (usp. tablicu 1). ${ }^{43}$

Tablica 1. Lijevoekstremistički ljudski potencijal 2003.-2005.

\begin{tabular}{|l|c|c|c|c|c|c|}
\hline \multirow{2}{*}{ Lijevoekstremistički potencijal } & \multicolumn{2}{c|}{2003.} & \multicolumn{2}{c|}{2004.} & \multicolumn{2}{c|}{2005.} \\
\cline { 2 - 7 } & grupe & osobe & grupe & osobe & grupe & osobe \\
\hline nasilni lijevi ekstrem. & 55 & 5.400 & 61 & 5.500 & 67 & 5.500 \\
\hline $\begin{array}{l}\text { marks.-lenjin. i ostale } \\
\text { organizacije i stranke }\end{array}$ & 49 & 26.300 & 49 & 25.700 & 43 & 25.400 \\
\hline Ukupno & & 31.700 & & 31.200 & & 30.900 \\
\hline nakon odbijenog višestrukog članstva & & $\begin{array}{c}\text { cca } \\
31.300\end{array}$ & & $\begin{array}{c}\text { cca } \\
30800\end{array}$ & & $\begin{array}{c}\text { cca } \\
30.600\end{array}$ \\
\hline "Die Linke. PDS« & & $\begin{array}{c}\text { cca } \\
65.800\end{array}$ & & $\begin{array}{c}\text { cca } \\
61.400\end{array}$ & & $\begin{array}{c}\text { cca } \\
61.500\end{array}$ \\
\hline
\end{tabular}

Što se tiče lijevoekstremističkog ljudskog potencijala proteklih nekoliko godina, u razdoblju od 2016. do 2018. godine on je izgledao ovako ${ }^{44}$ (usp. tablicu 2):

\footnotetext{
${ }^{42}$ Bulletin der Bundesregierung 34-94, Der Verfassungsschutz als Beitrag zur Erhaltung und Sicherung des demokratischen Gemeinwesens - Erklärung des Bundesministers des Innern, 20. travnja 1994.

${ }^{43}$ Verfassungsschutzberichte 2003-2005.

${ }^{44}$ https://www.verfassungsschutz.de (04.12.2019).
} 
Tablica 2. Lijevoekstremistički ljudski potencijal 2016.-2018. ${ }^{45}$

\begin{tabular}{|l|c|c|c|}
\hline \multicolumn{1}{|c|}{ Lijevoekstremistički potencijal } & $\mathbf{2 0 1 6 .}$ & $\mathbf{2 0 1 7 .}$ & $\mathbf{2 0 1 8 .}$ \\
\hline $\begin{array}{l}\text { lijevi ekstremisti orijentirani na nasilje } \\
\text { od toga: }\end{array}$ & 8.500 & 9.000 & 9.000 \\
\hline »autonomni« & 6.800 & 7.000 & 7.400 \\
\hline anarhisti & 800 & 800 & 800 \\
\hline dogmatski lijevi ekstremisti & - & - & 800 \\
\hline $\begin{array}{l}\text { dogmatski lijevi ekstremisti koji nisu orijentirani na nasilje i } \\
\text { ostali lijevi ekstremisti }\end{array}$ & 20.900 & 21.400 & 24.000 \\
\hline Ukupno & 29.400 & 30.400 & 33.000 \\
\hline Nakon odbijenog višestrukog članstva & 28.500 & 29.500 & 32.000 \\
\hline
\end{tabular}

Što se tiče akcijskih oblika djelovanja lijevih ekstremista, njih bismo grubo mogli podijeliti u dvije kategorije: javne, odnosno konfrontacijske i tajne. Prilikom velikih demonstracija lijevi ekstremisti traže direktnu konfrontaciju is političkim neistomišljenicima is policijom. Osim toga, nasilni lijevi ekstremisti izvode i tajne napade, a ciljevi su zgrade i vozila, najčešće policije, ali i tvrtki, željeznice itd. Pritom je riječ o namjeri izazivanja manje ili veće materijalne štete. Počinitelji žele privući medijsku pažnju, kako bi javnosti mogli bolje prezentirati svoje političke ciljeve. Policija je omiljeni cilj nasilnih lijevih ekstremista, za njih su policijski službenici gotovo dehumanizirani objekti mržnje. Takva percepcija olakšava lijevim ekstremistima opravdanost njihovih postupaka, jer iz njihove perspektive njihove se akcije ne usmjeravaju protiv ljudi, nego "samo" protiv dijelova navodne represijske mašinerije; »dnevne policijske žrtve su samo potrebne kolateralne žrtve...« «6

Od oblika djelovanja lijevih ekstremista, svakako treba spomenuti tzv. »outing « akcije, praksu javnog otkrivanja identiteta političkih protivnika, odnosno stvarnih ili tobožnjih desnih ekstremista. Konkretno, lijevi ekstremisti publiciraju informacije o određenim osobama s ciljem da ih se zastraši. Kada je riječ o nasilju, odnosno o kaznenim djelima koja čine (ne samo) lijevi ekstremisti, svakako treba spomenuti činjenicu da je 2001. godine u SR Njemačkoj uveden sustav definiranja »Politički motiviran kriminalitet», a središnji kriterij je bio ustanoviti postoji li politička motivacija neke kriminalne radnje. Podaci koji slijede o političkim motiviranim deliktima s lijevoekstremističkom pozadinom za 2003. i 2004. godinu temelje se na podacima njemačkog Saveznog kriminalističkog ureda (Bundeskriminalamt - BKA) i objavljeni su u godišnjim izvještajima Saveznog ureda za zaštitu ustava (usp. tablicu 3).

\footnotetext{
${ }^{45}$ U izvješću Ureda za zaštitu ustava je 2018. godine promijenjen način klasifikacije i prikaza lijevoekstremističkog ljudskog potencijala. Zbog toga se i tablica s podacima za 2018. godine vizualno i djelomice sadržajno razlikuje od prijašnjih tablica.

${ }^{46}$ Internetplattform »chronik.blackblogs«, 17. ožujka 2017; https://chronik.blackblogs.org/ (02.10.2019).
} 
Tablica 3. Politički motiviran kriminal 2003-2004. (lijevi ekstremizam) ${ }^{47}$

\begin{tabular}{|l|c|c|}
\hline \multicolumn{1}{|c|}{ Nasilna djela: } & $\mathbf{2 0 0 3 .}$ & $\mathbf{2 0 0 4 .}$ \\
\hline ubojstva & 0 & 0 \\
\hline pokušaji ubojstva & 1 & 0 \\
\hline nanošenje tjelesnih ozljeda & 192 & 226 \\
\hline podmetanje požara & 36 & 31 \\
\hline podmetanje eksploziva & 0 & 0 \\
\hline ometanje posjeda & 118 & 144 \\
\hline $\begin{array}{l}\text { opasne radnje u željezničkom, zračnom, brodskom i cestovnom } \\
\text { prometu }\end{array}$ & 29 & 19 \\
\hline otmice & 0 & 0 \\
\hline pljačke & 5 & 12 \\
\hline ucjene & 0 & 1 \\
\hline pružanje otpora & 102 & 88 \\
\hline seksualni delikti & 0 & 0 \\
\hline Ukupno & 483 & 521 \\
\hline & 2003. & 2004. \\
\hline materijalna šteta & 510 & 490 \\
\hline prijetnje & 35 & 19 \\
\hline ostala kaznena djela & 431 & 410 \\
\hline Ukupno & 976 & 919 \\
\hline Kaznena djela ukupno & 1.459 & 1.440 \\
\hline
\end{tabular}

Nasilna i ostala kaznena djela s ekstremističkom pozadinom iz područja proteklih nekoliko godina daju nam sljedeću sliku (usp. tablicu 4).

Tablica 4. Politički motiviran kriminal 2016-2018. (lijevi ekstremizam) ${ }^{48}$

\begin{tabular}{|l|c|c|c|}
\hline \multicolumn{1}{|c|}{ Nasilna djela: } & $\mathbf{2 0 1 6 .}$ & $\mathbf{2 0 1 7 .}$ & $\mathbf{2 0 1 8 .}$ \\
\hline ubojstva & 0 & 0 & 0 \\
\hline pokušaji ubojstva & 6 & 3 & 0 \\
\hline nanošenje tjelesnih ozljeda & 638 & 499 & 363 \\
\hline podmetanje požara & 134 & 145 & 108 \\
\hline podmetanje eksploziva & 7 & 5 & 1 \\
\hline ometanje posjeda & 186 & 784 & 90 \\
\hline $\begin{array}{l}\text { opasne radnje u željezničkom, zračnom, brodskom i cestovnom } \\
\text { prometu }\end{array}$ & 50 & 63 & 48 \\
\hline otmice & 1 & 0 & 1 \\
\hline pljačke & 23 & 12 & 19 \\
\hline ucjene & 1 & 2 & 4 \\
\hline
\end{tabular}

\footnotetext{
${ }^{47}$ Podaci, osim onih koji se odnose na ubojstva, uključuju izvršena kaznena djela, kao i ona u pokušaju. Ako je istovremeno izvršeno nekoliko kaznenih djela, onda se ubrojilo samo najteže kazneno djelo (Verfassungsschutzbericht, 2005).

${ }^{48}$ Verfassungsschutzberichte 2016-2018.
} 


\begin{tabular}{|l|c|c|c|}
\hline pružanje otpora & 155 & 135 & 376 \\
\hline Ukupno & 1.201 & 1.648 & 1.010 \\
\hline materijalna šteta & & & \\
\hline prijetnje & 2.233 & 3.190 & 2.219 \\
\hline ostala kaznena djela & 112 & 80 & 71 \\
\hline Ukupno & 1.684 & 1.475 & 1.322 \\
\hline Ukupno kaznena djela & 4.029 & 4745 & 3.612 \\
\hline
\end{tabular}

Grafički prikazano, broj nasilnih djela lijevih ekstremista u SR Njemačkoj u razdoblju od 2008. - 2018. izgleda ovako ${ }^{49}$ (usp. grafikon 1).

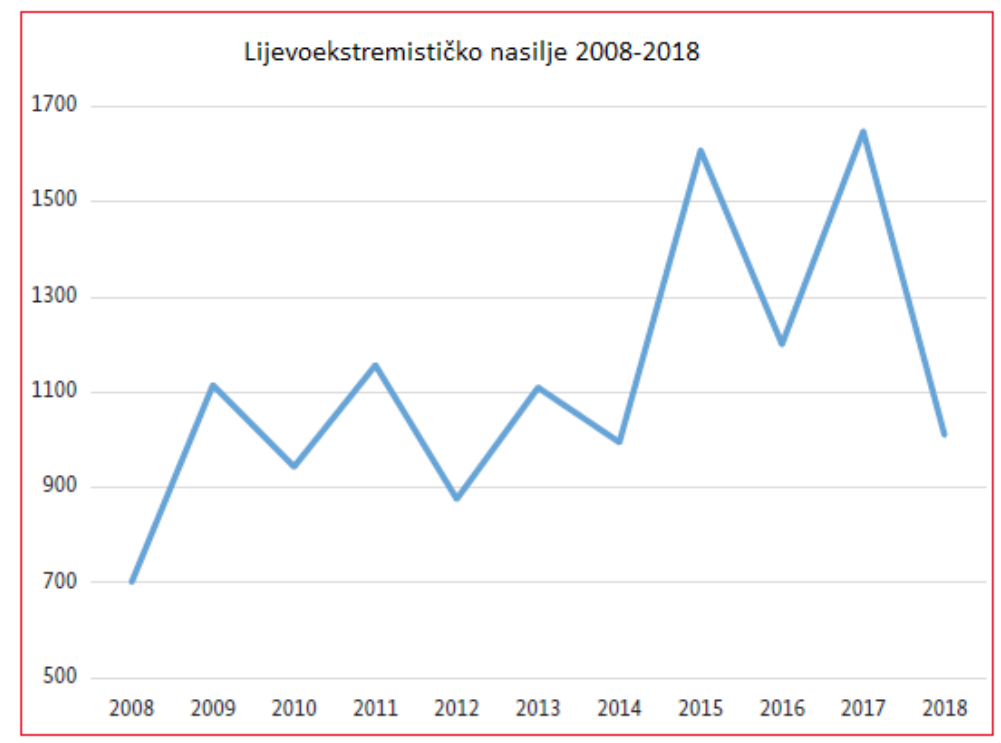

Grafikon 1. Lijevoekstremističko nasilje 2008.-2018.

Kako je vidljivo iz grafikona i iz prethodnih tablica, 2018. godine je broj nasilnih djela u odnosu na 2017. godinu smanjen, međutim uzrok tome treba tražiti u nedostatku nekog velikog i značajnog događaja koji bi po svom sadržaju mogao mobilizirati cijelu lijevoekstremističku scenu. Primjerice, 2017. godine takav je događaj bio sastanak na vrhu čelnika država članica G20 u Hamburgu, kada je eskaliralo lijevoekstremističko nasilje. Ako se pak pogledaju brojke posljednjih desetak godina, onda se ipak može uočiti porast lijevoekstremističkih kaznenih djela. Međutim, porast nije linearan, nego se naglo povećanje može uočiti prilikom skupova ili događaja koji su relevantni za lijevoekstremističku scenu, poput već spomenutog samita G20.

\footnotetext{
${ }^{49}$ Verfassungsschutzbericht 2018, 120.
} 


\section{Zaključak}

Analiza lijevog ekstremizma u SR Njemačkoj, ideoloških temelja, tematskih područja djelovanja, ljudskog potencijala, odnosno članstva u strankama i organizacijama te akcijskih oblika i strategija, od ujedinjenja dviju njemačkih država do danas, može se zaključno sažeti u sljedećem: prvo, i najvažnije, lijevi ekstremizam u SR Njemačkoj nije niti u jednom trenutku ozbiljnije ugrozio njemačku demokraciju. Usprkos tome, on nije zanemariv, te zbog svog ukupnog potencijala dodatno u mnogim segmentima, pa i u financijskom dijelu, opterećuje demokratski poredak SR Njemačke. Nakon zabrane KPD-a 1956. godine, sve do ujedinjenja dviju njemačkih država lijevoekstremističke stranke nisu postigle zapaženije izborne uspjehe, a nakon ujedinjenja vrlo zapažene izborne uspjehe postiže stranka DIE LINKE, koju međutim, ne bismo u cjelini mogli opisati lijevoekstremističkom. Usprkos tome, unutar nje djeluju pojedine platforme, detaljnije opisane u prethodnim poglavljima, koje bismo po njihovim ciljevima mogli smjestiti u područje lijevog ekstremizma. Ako se uspjesi stranke DIE LINKE ne uzmu u obzir, onda razdoblje nakon njemačkog ujedinjenja do danas nije donijelo nikakve značajnije promjene u odnosu na lijevoekstremističku organiziranu, stranačku scenu neposredno prije ujedinjenja, dakle krajem osamdesetih godina.

Drugo, lijevi je ekstremizam sedamdesetih godina dvadesetog stoljeća prerastao u lijevi terorizam koji je odnio mnoge ljudske živote. Prisjetimo se djelovanja i akcija Rote Armee Fraktion, kada je u tridesetak godina njezinog aktivnog djelovanja izvršeno 26 terorističkih akcija i ubijeno 34 ljudi, a iz redova RAF-a stradalo 20 članova. ${ }^{50}$ Nakon ujedinjenja, nasilni lijevoekstremistički potencijal nije kulminirao stvaranjem i djelovanjem neke veće terorističke ćelije koja bi dostigla dimenzije djelovanja RAF-a. Dok je broj "autonomnih" spremnih na nasilje 1992. godine iznosio oko 5.000 osoba, ukupan broj lijevih ekstremista sklonih nasilju je 2018. godine, prema procjeni Saveznog ureda za zaštitu ustava, bio oko 9.000 ljudi. Broj kaznenih djela lijevih ekstremista 2018. godine, iako se smanjuje u odnosu na prethodne dvije godine, ipak je više od tri puta veći nego primjerice 2003. i 2004. godine, dakle, uočava se povećanje (usp. tablice 3. i 4.). Međutim, porast nije linearan, nego naglo raste prilikom manifestacija, odnosno skupova koji po svom sadržaju mogu mobilizirati lijevoekstremističku scenu. Treće, ukupan broj lijevih ekstremista u SR Njemačkoj od ujedinjenja do danas blago varira i iznosi u prosjeku oko 30.000 osoba (1992.: 29.000; 2005.: 30.600; 2016.: 28.500; 2018.: 32.000)..$^{51}$

\footnotetext{
${ }^{50}$ Bundeskriminalamt, 60 Jahre Staatsschutz im Spannungsfeld zwischen Freiheit und Sicherheit. Rote Armee Fraktion (RAF). Die Herausforderung für das Bundeskriminalamt als Zentrale Ermittlungsbehörde. Günther Scheicher, Abteilungspräsident a.D; https://www.bka.de (17.10.2019).

${ }^{51}$ Verfassungsschutzberichte 1990-2018.
} 
Na kraju valja naglasiti da koncept »borbene demokracije« SR Njemačke, ${ }^{52}$ a sažeto rečeno riječ je o preventivnoj zaštiti demokracije koja se brani od ekstremističkih pozicija i prije nego što ekstremističke grupacije prekrše zakon, dobro nadzire lijevoekstremističke pojave. Budući da taj koncept, između ostaloga, uključuje i mogućnost zabrane političkih stranaka i organizacija, možemo istaknuti činjenicu da je od siječnja 1990. godine do prosinca 2018. Savezno ministarstvo unutarnjih poslova zbog protuustavnog djelovanja zabranilo samo jednu lijevoekstremističku udrugu, odnosno organizaciju, i to »linksunten. indymedia« u kolovozu 2017. godine.

Za usporedbu, desnoekstremističkih je organizacija i udruga od 1964. do danas Savezno ministarstvo zabranilo njih 17, a 21 iz područja islamizma, odnosno stranog ekstremizma. »Linksunten.indymedia« je bila najvažnija internetska platforma nasilnih lijevih ekstremista u Njemačkoj. Ona se koristila za širenje priloga $s$ kažnjivim i protuustavnim sadržajima. Još se može istaknuti da su mjere koje njemačka država provodi radi suzbijanja i prevencije desnog ${ }^{53} \mathrm{i}$ lijevog političkog ekstremizma, odnosno političkog ekstremizma općenito, vrlo slojevite i sveobuhvatne. Kad je riječ o mjerama koje se odnose na lijevi ekstremizam, možemo istaknuti program Savezne službe za zaštitu ustava kojom se ljudima olakšava napuštanje lijevoekstremističke scene. ${ }^{54}$ Iako mogućnosti i potreba prevencije i suzbijanja političkog ekstremizma ovise o nizu faktora i različite su od zemlje do zemlje, mjere koje u tom segmentu koristi njemačka država zasigurno su primjenjive i izvan granica SR Njemačke.

\footnotetext{
${ }^{52}$ Damir VELIČKI, Koncept »borbene demokracije« u SR Njemačkoj, Politička misao, 44 (2007) 4, 35-54.

${ }^{53}$ Damir VELIČKI, Strategije suzbijanja i prevencija desnog ekstremizma u SR Njemačkoj, Društvena istraživanja, 19 (2010) 6, 1163-1181.

${ }^{54}$ Aussteigerprogramm für Linksextremisten - Beratung und Hilfe, https://www.verfassungsschutz.de (23.10.2019).
} 


\section{Damir Velički* \\ Left-wing Extremism in the Federal Republic of Germany Thirty Years After Unification \\ Summary}

Due to its historical burden, the Federal Republic of Germany has paid a great deal of attention to prevention and suppression of all extremist aspirations, including the left-wing extremism. The prerequisite for the analysis of the left-wing extremist tendencies in Germany is a clear definition of the very concept of political or left-wing extremism. Subsequently, after an overview of the ideological foundations of the left-wing extremism, the analysis is given of parties i.e. organizations within the left-wing extremist spectrum operating in the Federal Republic of Germany, their membership, actions, strategies and thematic areas of activity, with a goal to determine whether the left-wing extremism in that segment has increased since the German unification to date. The analysis concluded that the left-wing extremism in the Federal Republic of Germany, although, after the unification, has not at any point seriously compromised German democracy, is not negligible. Because of its overall potential, it burdens the democratic order of the Federal Republic of Germany in many segments, but simultaneously the layered measures implemented by the German state with a goal to suppress and prevent political extremism have been coping well with the phenomenon of left-wing extremism.

Key words: Federal Republic of Germany, left-wing extremism, political extremism, unification.

(na engl. prev. Diana Benković)

\footnotetext{
* Damir Velički, PhD, Assoc. Prof., University of Zagreb, Faculty for teacher education; Address: Savska c. 77, HR-10000 Zagreb, Croatia; E-mail: damir.velicki@ufzg.hr.
} 